\title{
Gastropod Diversity in Mangrove Forests of Mojo Village, Ulujami District, Pemalang Regency, Indonesia
}

\author{
Sri Puryono ${ }^{1 *}$, Suryanti Suryanti ${ }^{2}$ \\ 1 Regional Secretary, Province of Central Java, Indonesia \\ 2 Faculty of Fisheries and Marine Sciene, Diponegoro University, Semarang, Indonesia \\ * Corresponding author's e-mail: spuryonodr@gmail.com
}

\begin{abstract}
The development of mangrove ecosystem has a significant impact on fishery resources, such as gastropod. This research aimed at studying the community structure of mangrove forest in Mojo village, to identifying and analyzing the composition and diversity of gastropod, and investigating the effect of mangrove community on the abundance and gastropod. The research was conducted in Mojo Village, Ulujami District, Pemalang Region from November to December 2017. Identification of species and density was conducted on mangrove species by means of line and plot transects, while the gastropod was sampled from the field then identified in the laboratory. Three sampling stations were occupied in the data collection. The data analysis was conducted for diversity indices, including heterogeneity and evenness both for mangrove and gastropod. Statistical data analysis was conducted by regression to analyze the effect of mangrove density on the abundance of gastropod. The result showed that only three mangrove species were found in Mojo village, including Rhizophora mucronata, Avicennia marina and A. officinalis. Eight gastropod species were identified from mangrove forest of Mojo village. The most dominant gastropod species was Telescopium telescopium, followed by Cerithidea cingulata. The analysis of heterogeneity index showed a low value for mangrove community and medium value for the gastropod community, ranging from 0.353 to 0.720 and 1.462 to 1.812 , respectively. Statistical data analysis showed that the density of $R$. mucronata and A. marina had a significant effect on the abundance of gastropod specieses, including Cerithidea quadrata and Casidula nucleus, both of which had logarithmic relationship trends.
\end{abstract}

Keywords: density, diversity, gastropod, logarithmic, mangrove

\section{INTRODUCTION}

Gastropods are the largest group of species in the shallow water (Santhiya et al., 2013). However, the distribution of gastropod is not limited to the aquatic environment, but also to the terrestrial area (Astor et al., 2015). Mangrove constitutes an ecosystem existing in the intertidal area, considered as the highly suitable habitat for gastropod (Zvonareva et al., 2015). Gastropods constitute the most common mollusk found in mangrove area (Pribadi et al., 2009). The wide distribution area of gastropods indicates their importance to the ecosystem. Thus, the community of gastropods may also be different according to the associated environment.
Gastropods are a group of organisms with economic and ecological importance for the coastal area. They are litter feeders which consume fallen plant leaves. Thus, gastropods could be considered as one of decomposers in the ecosystem. The feeding activity of gastropods produces faeces and mucus which provide suitable habitat for microorganisms (Astor et al., 2015). Thus, the existence of gastropods affects the micro-ecological condition of an ecosystem (Ramanibai and Govindan, 2018). Moreover, the structural composition and abundance of particular species may emphasize the role of gastropod community in the ecosystem.

Some gastropod species are also identified as mangrove litter feeder (Tavares et al., 2015), 
while some others are filter feeders (Khade and Mane, 2012). Thus, the gastropod community has significant role in the nutrient cycle. Ecologically, the grazer gastropods can control the population of epiphytic algae and hinder algal bloom (Picardal and Dolorosa, 2014). In the long period of time, there was a difference of species composition, density, and gastropod collection biomass on the mangrove ecosystem (Zvonareva et al., 2015). Another ecological role of gastropods is as a biological indicator of environmental change in an ecosystem (Irma and Sofyatuddin, 2011).

Gastropods also have economic value for various usages. The trading of gastropods had been conducted for various purposes such as for food source and ornaments (Santhiya et al., 2013). The demand for edible gastropods for human consumption tends to increase, which even caused overfishing (Flores-Garza et al., 2012). However, not all of the gastropod species could be considered as edible. Some gastropod species are considered as pollutant bioaccumulators, including toxic compounds (Jen et al., 2014). Thus, selective capture should be applied to achieve food security. However, gastropods are also utilized for some other purposes, such as medicine, jewellery, tools and pets (Ramanibai and Govindan, 2018). Thus, the potential of gastropod utilization is widely opened and may alter its capture.

A mangrove ecosystem had been known to have a large biodiversity. Various fauna species inhabit the mangrove forest due to its environmental services in providing shelter, protection, food, and habitat suitability. The mangrove ecosystem consists of various associated fauna, such as gastropods. However, the composition of species, abundance, diversity and biomass of gastropod change according to the condition of the mangrove ecosystem (Zvonareva et al., 2015). The environmental dynamic of mangrove ecosystem might affect the composition of gastropods within. A lot of gastropod species in the coastal ecosystem are dependent on the mangrove forest due to its capability to adapt the environment. Gastropod species are found attached to various part of mangrove plants such as roots, trunk, branches or leaves (Manullang et al., 2018).

The composition of gastropods within mangrove ecosystem also indicates its ecological condition as well as its environmental quality (Zvonareva et al., 2015). The species and size of gastropods define the feeding capacity as well as the production of mucus and faeces (Astor et al., 2015). Some gastropod species are known to prefer litter source as feed (Astor et al., 2015). Thus, the source of the litter might also affect the composition of gastropods (Kottè-mapoko et al., 2017). The mangrove ecosystem supports the biological diversity of the coastal area due to its rich organic matter and nutrients (Khade and Mane, 2012). However, the mangrove ecosystem is also considered as the most dynamic ecosystem. Thus, the suitability of habitat for gastropods may change over time, which further affects the composition of the biota.

Increasing exploitation of coastal area had a diversified impact on the related ecosystem, including the mangrove ecosystem. Mangrove forests in many regions were degraded by various activity, such as fish farming, area development, as well as the impact of upland area (Premcharoen et al., 2016). However, mangrove - which has important value for coastal ecosystem should be conserved to maintain the sustainability of the resources. Thus, the application of sustainable management practice should be conducted to achieve the objective.

Mojo village is an area in Pemalang, in which the mangrove forest was degraded as the impact of increasing aquaculture activity. The mangrove forest in Mojo village only covers the area of 88.57 hectares (Fatmawati et al., 2016). Unfortunately, the coverage is only $14.47 \%$ of the total are of brackish water ponds. Meanwhile, fishermen constitute one of the dominant professions in the Mojo village's community (Purnamawati et al., 2015). Thus, the sustainability of the mangrove forest in Mojo village has an important role in supporting the livelihood of the local community. One of the direct advantages of the mangrove forest in Mojo village is the capture of fish, including shellfish. However, the potential of gastropods as fisheries resource is not well understood.

The economic value of gastropods had caused an increased fishing activity and depleted population. However, the replantation of mangrove forest may improve the environmental quality to support the habitat suitability of some gastropod species. This research aimed at studying the community structure of mangrove forest in Mojo village, identifying and analyzing the composition and diversity of gastropod, and investigating the effect of mangrove community on the abundance of gastropods. 


\section{MATERIALS AND METHODS}

The study was conducted from November to December 2017 in the Mojo village mangrove forest. Sampling consists of 3 stations and each station is made 1 line transect made perpendicular to the coastline with a $20 \mathrm{~m}$ distance between lines. The resultant plots have the area of $10 \times 10 \mathrm{~m}$; there are five plots in each line. Observation of the mangrove vegetation involved a $10 \times 10 \mathrm{~m}$ plot and on site species identification.

The sampling of gastropods was carrued out using a quadrant measuring $1 \times 1 \mathrm{~m}$. Five quadrants were placed randomly on the $10 \times 10 \mathrm{~m}$ plot. Gastropods were taken by hand (hand picking), found on the surface of the soil and attached to the mangrove tree. The samples can be cleaned and preserved with $4 \%$ formalin and $70 \%$ alcohol. The samples were identified according to Dharma (1988), (Carpenter and Niem, 1998), and related sites. The water chemistry physics parameters measured include water temperature, water salinity, soil salinity, water $\mathrm{pH}$, soil $\mathrm{pH}$, and soil texture. Measurements of parameters other than soil texture were conducted in situ by taking logged water samples or in pore water which were mostly found in the sample observation plot, then measured each parameter three replication at each observation station along with the sampling. The soil texture measurements were done with soil jar test with depth of soil samples taken at a depth of $10 \mathrm{~cm}$.

The abundance of mangrove is expressed as the number of trees per area (trees/ha), while the gastropods are expressed as individuals per area (indv/ha). Thus, the data collected from field observation (mangrove) and laboratory identification of samples (gastropod) were both converted to a consistent area unit. Further data processing was conducted to calculate the diversity indices, including the heterogeneity and evenness of mangrove and gastropods. The calculation was conducted with Shannon-Wiener formula:

$$
H^{\prime}=-\sum p i \ln (p i)
$$

where: $H^{\prime}=$ heterogeneity index

$P i=$ relative abundance of mangrove / gastropod, achieved from ni/N $n i=$ abundance of species $-\mathrm{i}$ $N=$ total abundance of all identified species

$$
E=\frac{H^{\prime}}{\ln S}
$$

where: $E=$ evenness index

$S=$ total number of mangrove/gastropod species

Further analysis was conducted through statistical analysis with regression. However, due to the complexity of the data, data reduction was conducted by PCA. Thus, particular data could be selected to conduct appropriate statistical analysis. Regression analysis was conducted through curve estimation. Thus, instead of only knowing the effect of the mangrove abundance on gastropods, the pattern of the effect could be understood as well. The statistical data analysis was conducted with SPSS 19.

\section{RESULT}

The observation on the composition of mangrove plants showed that only three species existed in the mangrove forest of Mojo Village, including Rhizophora mucronata, Avicennia marina and $A$. officinalis. The density of mangrove plants at each station was very low with total density less than 1,000 trees/ha. Complete observation results along with the diversity indices at each station are presented in Table 1 .

According to the observation result, as presented in Table $1, R$. mucronata dominated the composition of the mangrove vegetation in the Mojo Village. The density was much higher than of other mangrove species. On the other hand, A. Officinalis had the lowest density and was only found in station 2 and station 3. The analysis on the diversity indices showed low values of heterogeneity (less than 1), while the evenness was categorized as low in station 1 and fair in station 2 and station 3 .

The measurement of environmental quality, both water and soil quality of mangrove floor was conducted to describe the condition of the habitat for gastropod. According to the measurement, the environmental quality among stations varied slightly. Complete measurement data of environmental quality of mangrove floor is presented in Table 2.

Table 2 shows that the water temperature in the sampling stations was warm and nearly similar. The salinity was observed as brackish, since the measurements showed the value of less than 
Table 1. Composition and diversity indices of mangrove in Mojo Village (trees/ha)

\begin{tabular}{|c|l|c|c|c|}
\hline \multirow{2}{*}{ No. Spesies } & \multicolumn{2}{|c|}{ Abundance } \\
\cline { 3 - 4 } & & Station I & Station II & Station III \\
\hline 1. & Rhizopora mucronata & 550 & 480 & 500 \\
\hline 2. & Avicennia marina & 70 & 160 & 120 \\
\hline 3. & Avicennia officinalis & - & 20 & 50 \\
\hline & Total & 620 & 660 & 670 \\
\hline & H' & 0,353 & 0,681 & 0,720 \\
\hline & $\mathrm{E}$ & 0,509 & 0,620 & 0,655 \\
\hline
\end{tabular}

Table 2. Physical and chemical quality in the mangrove forest of Mojo Village

\begin{tabular}{|c|l|c|c|c|}
\hline No. & \multicolumn{1}{|c|}{ Parameter } & Station I & Station II & Station III \\
\hline 1 & Water Temperature $\left({ }^{\circ} \mathrm{C}\right)$ & 31 & 30 & 30 \\
\hline 2 & Water Salinity $(\mathrm{ppt})$ & 27 & 26 & 26 \\
\hline 3 & Soil Salinity $(\mathrm{ppt})$ & 26 & 26 & 25 \\
\hline 4 & Water $\mathrm{pH}$ & 8 & 8 & 8 \\
\hline 5 & Soil $\mathrm{pH}$ & 6 & 6 & 6 \\
\hline 6 & Soil Texture & Sandy loam & Sandy loam & Loam \\
\hline
\end{tabular}

30 ppt at all stations. Soil salinity was brackish as well. There was no significant difference of salinity between the water and soil. There was a difference in the $\mathrm{pH}$ of water and soil. The $\mathrm{pH}$ of water was slightly alkaline, while the $\mathrm{pH}$ of the soil was slightly acidic, indicating different concentration of organic matter. The soil textures were dominated by silt; however, at station 1 and station 2 the sediments tended to be sandy.

Identification of gastropod resulted in finding a total of 8 species in the mangrove forest of Mojo village. However, at station 1 and station 2, only 7 species were found. The most dominant species at station 1 and station 2 was Telescopium telescopium, while at station 3 - Cerithidea cingulata. The identification showed that the abundance of gastropods in the mangrove forest of Mojo vil- lage was relatively low. Complete identification results of gastropods are presented in Table 3 .

According to the identification results presented in Table 3, the abundance of gastropods was varied among species. The proportion of species abundance at each station was also varied. Among the identified gastropod species, $C$. Scripta was not found at station 1, while at station $2 \mathrm{~N}$. violacea was absent. Thus, 7 species of gastropods were identified at both stations. The highest total abundance of gastropods was identified at station one. Meanwhile, station 3 - which had the most gastropod species - also had the lowest total gastropod abundance.

The analysis of the diversity indices showed that the gastropod composition at each sampling station had fair heterogeneity. However, the het-

Table 3. Abundance and diversity indices of gastropods in mangrove forest of Mojo Village (indv/ha)

\begin{tabular}{|c|l|c|c|c|}
\hline No. & \multicolumn{1}{|c|}{ Spesies } & Station I & Station II & Station III \\
\hline 1 & Cerithidea cingulata & 16.200 & 16.600 & 16.800 \\
\hline 2 & Cerithidea quadrata & 9.000 & 4.400 & 6.000 \\
\hline 3 & Littorina scabra & 6.200 & 5.800 & 9.600 \\
\hline 4 & Littorina angulifera & 3.400 & 1.200 & 4.200 \\
\hline 5 & Casidula nucleus & 3.800 & 6.000 & 5.200 \\
\hline 6 & Columbella scripta & - & 1.400 & 3.800 \\
\hline 7 & Neritina violacea & 2.200 & - & 400 \\
\hline 8 & Telescopium telescopium & 36.600 & 31.400 & 62.000 \\
\hline & Total Abundance & 77.400 & 66.800 & 8 \\
\hline & Number of Species & 7 & 7 & 1,812 \\
\hline & H' & 1,520 & 1,462 & 0,871 \\
\hline
\end{tabular}


erogeneity in station 3 was the highest, while station 2 had the lowest index. However, the analysis of the evenness index showed that all stations had high evenness of gastropod abundance. This result indicated that the site had low domination of certain gastropod species.

The next analysis was regression, conducted to provide the statistical evidence of the effect of mangrove density on the abundance of gastropods. However, to further understand about the effect, the analysis was conducted not only to the total abundance but also to the particular species. Unfortunately, the analysis which involved species would be ineffective. Thus, principal component analysis (PCA) was conducted to reduce the data. Every single environmental parameter, mangrove species, and gastropod species abundance were involved. However, data screening resulted in the exclusion of environmental parameters due to inappropriate distribution (no variation), or lack of have normal distribution. The analysis result of PCA is presented in Figure 1 and Table 4. Component matrix resulted from PCA.

According to the results of PCA, the variables could be grouped into two components. However, between the two components, the mangrove related variables including the abundance of $R$. mucronata, A. marina and the total mangrove abundance were grouped in one component. Gastropod species were distributed into two components. However, three of them were in the same group with mangrove, including C. quadrata, $C$. nucleus, and $C$. cingulate, plus total abundance of gastropods. Thus, the regression analysis was conducted to the mentioned variables, involving the mangrove density as the independent variable and gastropod abundance as dependent variable.

There were four significant relationships achieved from the analysis. However, only two species of gastropods were related to the density of mangrove, i.e. C. quadrata and C. nucleus. Both where affected significantly by the density of $R$. mucronata and A. marina. The regression analysis was conducted by curve estimation.

The first analysis of the effect of mangrove density on the abundance of gastropod was shown by $C$. quadrata. Both mangrove species, $R$. mucronata and A. marina separately affected the abundance of $C$. quadrata. Since the simulatenous effect could not be conducted due to data limitation. The relationship between mangrove density and the abundance of C. quadrata is presented in Figure 2.
Figure 2 shows that the effect of mangrove species was opposite. The curve estimation showed that both $R$. mucronata and A. marina affected the density of $C$. quadrata in logarithmic model. The density of $R$. mucronata tended to have a positive effect on the C. quadrata following the formula of $\mathrm{Y}=333,380 \cdot \ln (\mathrm{x})-201,585$, while the effect of $A$. marina had a negative effect following the formula of $\mathrm{Y}=-5,565 \cdot \ln (\mathrm{x})+$ 23,641 . Thus, increasing the density of $R$. mucronata would promote the increasing abundance of C. quadrata. Inversely for $A$. marina where the increasing density will lead to the decrease of its abundance. The analysis resulted the determination coefficient of $99.72 \%$ for $R$. mucronata and $100 \%$ for $A$. marina with probability of 0.034 and 0.000 , respectively. This means that the relationships were significant.

Contrary to the C. quadrata, the effect of mangrove density on the abundance of $C$. nucleus

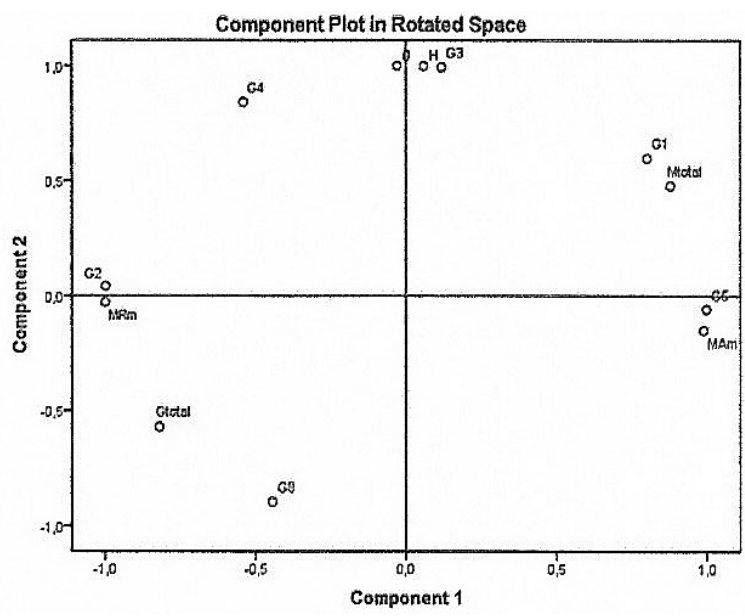

Figure 1. Principal component distribution diagram

Table 4. Component matrix resulted from PCA

\begin{tabular}{|l|c|c|}
\hline \multirow{2}{*}{ Rotated Component Matrix } & \multicolumn{2}{c|}{ Component } \\
\cline { 2 - 3 } & 1 & 2 \\
\hline Rhizophora mucronata & $-1,000$ & \\
\hline Cerithidea quadrata &,- 999 & \\
\hline Casidula nucleus &, 998 & \\
\hline Avicennia marina &, 989 & \\
\hline Mangrove total &, 878 &, 478 \\
\hline Gastropod total &,- 821 &,- 571 \\
\hline Cerithidea cingulata &, 801 &, 599 \\
\hline E Gastropod & & 1,000 \\
\hline H' Gastropod & &, 998 \\
\hline Littorina scabra & &, 993 \\
\hline Telescopium telescopium &,- 444 &,- 896 \\
\hline Littorina angulifera &,- 541 &, 841 \\
\hline
\end{tabular}




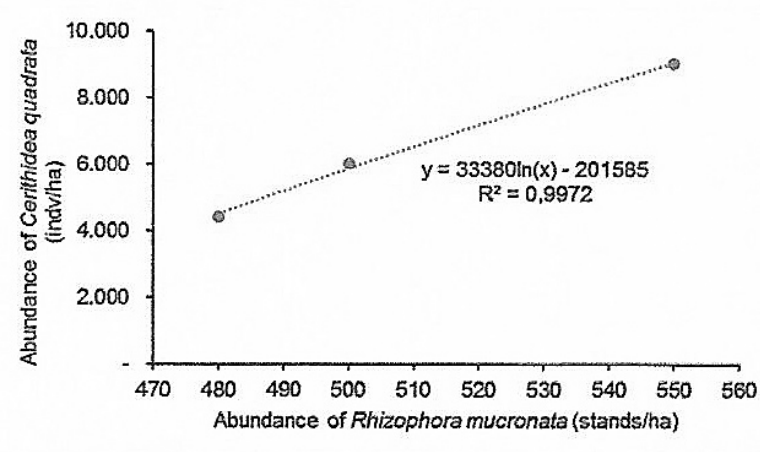

(a)

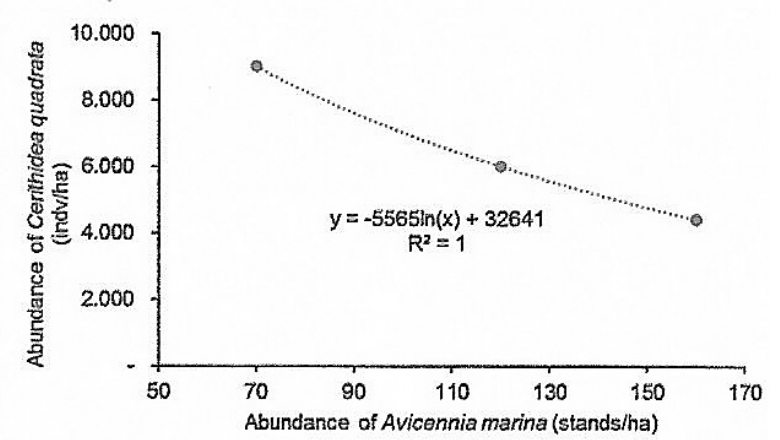

(b)

Figure 2. The effect of mangrove density on the total density of Cerithidea quadrata: (a) Rhizophora mucronata; (b) Avicennia marina

showed a completely different pattern. $R$. mucronata had a negative effect on the abundance of $C$. nucleus, while $A$. marina showed a positive effect. The curve estimation analysis resulted that $R$. $m u$ cronata had exponential pattern, while the effect of $A$. marina had logarithmic pattern. Figure 3 shows the relationship between mangrove density and abundance of $C$. nucleus in the Mojo village.

The analysis resulting from $R$. mucronata provided the formula of $\mathrm{Y}=133,607 \cdot \mathrm{e}^{-0.006 x}$ with probability of 0.019 , while $A$. marina provided the formula of $2,653 \cdot 1 \cdot \ln (\mathrm{x})-7,479.3$ with probability of 0.011 . The coefficient of determination showed the values of $99.91 \%$ and $99.97 \%$ for $R$. mucronata and A. Marina, respectively. This indicated that the abundance of gastropods was highly dependent on the mangrove density.

\section{DISCUSSION}

The composition of mangrove community in Mojo village showed low diversity. There were only 3 species found during the research, including A. marina, A. officinalis and R. mucronata. This result indicates that there was a change of the mangrove composition in Mojo village. Previous research showed that the mangrove in Mojo village consisted of A. alba, A. marina and R. mucronata. The abundance of trees is also decreased, where the previous research showed the abundance of more than 3.000 trees/ha (Renta et al., 2016), this research indicated only 620-670 trees/ha.

The low diversity of mangrove community showed that the mangrove forest in Mojo village was a young forest. Young mangrove forest is generally dominated by single mangrove species due to replantation activity or appropriate environment condition (Cudiamat and Rodriguez, 2017). The current condition of mangrove forest in Mojo village is the result of replantation. The change of mangrove coverage had been recorded from 72 ha in 2014 (Purnamawati et al., 2015) to 88.57 ha in 2015 (Fatmawati et al., 2016).

Generally, gastropods prefer the habitats with clean water environment. It was proven that the

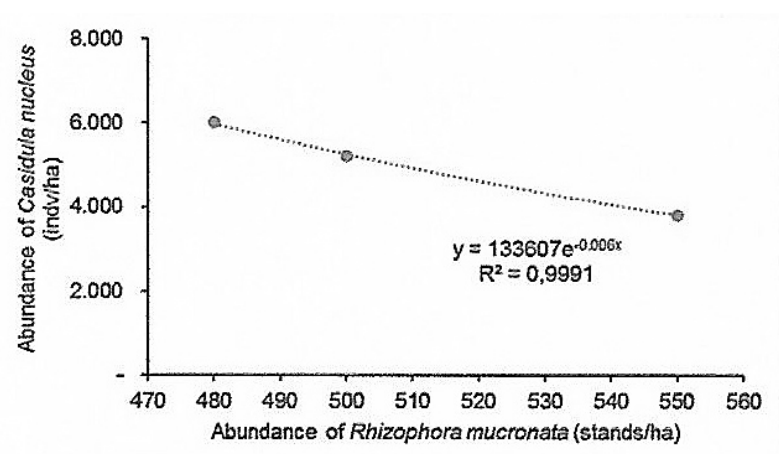

(a)

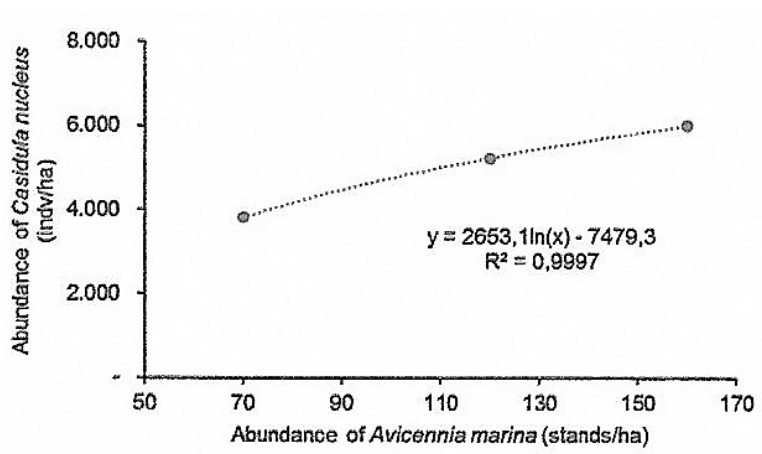

(b)

Figure 3. The effect of mangrove density on the total abundance of Casidula nucleus: (a) Rhizophora mucronata; (b) Avicennia marina 
species diversity was higher in the clean than in the turbid aquatic environment (Picardal and Dolorosa, 2014). Conversely, the concentration of TSS had a parabolic effect on the total abundance of gastropods (Suryanti et al., 2017). Another research related to mangrove forest showed that the concentration of organic matter significantly affected the abundance of gastropods (Tambayong et al., 2016). The concentration of organic matter in the sediment has a positive correlation toward the abundance of gastropods (Merly and Elviana, 2017). However, the abundance of gastropods is also affected by the habitat preference of particular species. The observation indicated the higher gastropod abundance in the station with sandy loam soil.

The composition of species was considered as low diversity. Only 8 gastropod species were identified in the mangrove forest of Mojo Village. The gastropod abundance and diversity is influenced by tree branches and mangrove leaf litter (Seena et al., 2017). This result was much lower than the diversity of gastropods in Lubuk Kertang Village which had 15 gastropod species (Manullang et al., 2018). It is also a slightly lower than the gastropod community observed in Aceh after 7 years of reclamation effort in the mangrove area which was damaged by tsunami, where 14 total gastropod species were identified (Irma and Sofyatuddin, 2011). This indicates that the mangrove forest in Mojo Village was less suitable for the gastropods.

Telescopium telescopium was the most abundant gastropod species. This indicates that the mangrove forest in Mojo village was rich in detritus as the main feed of T. telescopium (Zaman and Jahan, 2013). The abundance was linear to the density of mangrove suggested mangrove as the source of detritus. The increasing density of mangrove linearly correlated to the production of litter and detritus (Mulya and Arlen, 2018). Cerithidea cingulata was identified as the second most abundant species. This species prefers the habitats with low mangrove density (Silaen et al., 2013) which is appropriate to the result of this research.

The composition and abundance of gastropods in the mangrove ecosystem is significantly affected by mangrove composition (Manullang et al., 2018). The Mangrove species may have different associated gastropod species. Thus, more complex mangrove structure promotes greater diversity of gastropod species (Zvonareva et al., 2015). The microhabitat developed by mangrove community structure determines the species composition of gastropods in the mangrove floor (Tavares et al., 2015). The development of habitat occurs through several environment modifications, caused by physical and biological processes which affect the suitability for gastropod species.

The different composition of gastropod observed in the field was considered as the effect of mangrove composition, even though there was no statistical proof of this assumption. Some gastropod species tend to have prefered types of litter which later affect the species distribution and abundance of the gastropod (Astor et al., 2015). The number of gastropods tends to increase along with the development of mangrove forest (Santhiya et al., 2013). The stabilization of mangrove forest promotes the habitat suitability and increase food web complexity for the associated organisms. Variation on the sources and types of foods provides complex nutrients for various species. Thus, as long as mangrove is developing, the faunal composition would grow as well. Particularly, the volume of liter production also affects the abundance of gastropods (Kirchenbaur et al., 2017).

Planted mangrove forest is generally under development over a few decades. Thus, the transition of vegetation, environmental condition, as well as its associated fauna are frequently observed (Zvonareva et al., 2015). Currently, the mangrove forest in Mojo village is dominated by Rhizophora mucronata due to the replantation activities. However, the ecological condition might vary because of the tidal dynamic, sediment balance, and nutrient balance (Ismoyo et al., 2017). The difference in the gastropod composition among stations indicated the different stages of mangrove forest in Mojo Village. Young mangrove ecosystem is generally imbalanced, dominated by opportunistic gastropod species and the lack of mangrove associated species (Zvonareva et al., 2015).

A mangrove forest should be managed optimally to obtain sustainable support to the coastal ecosystems, including the resources of fisheries which are highly dependent on the mangrove ecosystem. Unfortunately, the participation of local community in the management of mangrove forest in Mojo village was extremely low (Raharja et al., 2013). Thus, in order to improve the function of mangrove ecosystem, a proper management plan should be devised. Moreover, the participation of local community should be emphasized, since they are the main stakeholder which is strongly 
dependent on the mangrove sustainability. However, in order to improve the participation, public awareness concerning the importance of mangrove sustainability should be increased as well.

\section{CONCLUSION}

Three mangrove species were identified in the Mojo village; the community was characterized by low diversity and was dominated by $R$. mucronata. Eight gastropod species were identified in the mangrove forest with medium diversity and the species composition was dominated by $T$. telescopium. The density of mangrove both $R$. mucronata and A. marina significantly affects the abundance of $C$. quadrata and C. nucleus with logarithmic trend.

\section{Acknowledgements}

The authors would like to thank Untung Ismoyo, SPi and Nur Cholis, MSi for their assistance in field data collection

\section{REFERENCES}

1. Astor T, Lenoir L, Berg MP. 2015. Measuring Feeding Traits of A Range of Litter-Consuming Terrestrial Snails: Leaf Litter Consumption, Faeces Production and Scaling with Body Size. Oecologia 178 (3), 833-845. DOI: 10.1007/s00442-015-3257-y.

2. Carpenter KE, Niem VH. 1998. FAO Species Identification Guide for Fishery Purposes. The Living Marina Resources of the Western Central Pacific. Volume 1: Seaweeds, Corals, Bivalves and Gastropods. Rome.

3. Cudiamat MA, Rodriguez RA. 2017. Abundance, Structure, and Diversity of Mangroves in a Community-Managed Forest in Calatagan, Batangas, Verde Island Passage, Philippines. Asia Pacific Journal of Multidisciplinary Research 5(3), 27-33.

4. Fatmawati RA, Suryanto A, Hendrarto B. 2016. Luasan dan Distribusi Mangrove di Kecamatan Ulujami Kabupaten Pemalang dengan Penggunaan Google Earth dan Software ArcGIS (Studi Kasus: Desa Pesantren, Desa Mojo dan Desa Limbangan). Maquares,5(4), 427-432.

5. Flores-Garza R, García-Ibáñez S, Flores-Rodríguez P, Torreblanca-Ramírez C, Galeana-Rebolledo L, Valdés-González A, Suástegui-Zárate A, Violante-González J. 2012. Commercially Important Marine Mollusks for Human Consumption in Acapulco, Mexico. Natural Resources, 3(1), 11-17.
DOI: $10.4236 / \mathrm{nr} .2012 .31003$.

6. Irma D, Sofyatuddin K. 2011. Diversity of Gastropods and Bivalves in Mangrove Ecosystem Rehabilitation Areas in Aceh Besar and Banda Aceh Districts, Indonesia. Aquaculture, Aquarium, Conservation \& Legislation International Journal of the Bioflux Society 5(2), 55-59.

7. Ismoyo U, Hendrarto B, Suryanti. 2017. Analisis Bahan Organik dengan Kualitas Tanah terhadap Ukuran Daun Bakau (Rhizophora mucronata Lamk) di Hutan Mangrove Desa Mojo, Ulujami, Pemalang. Journal of Fisheries Science and Technology 12(2), 134-138.

8. Jen HC, Anh-Tuyet Nguyen T, Wu YJ, Hoang T, Arakawa O, Lin WF, Hwang DF. 2014. Tetrodotoxin and Paralytic Shellfish Poisons in Gastropod Species from Vietnam Analyzed by High-Performance Liquid Chromatography and Liquid Chromatography-Tandem Mass Spectrometry. Journal of Food and Drug Analysis 22(2), 1-11. DOI: 10.1016/j.jfda.2013.09.005.

9. Khade SN, Mane UH. 2012. Diversity of Bivalve and Gastropod Molluscs in Mangrove Ecosystem from Selected Sites of Raigad District, Maharashtra, West coast of India. Recent Research in Science and Technology 4(10), 16-20.

10. Kirchenbaur T, Fartmann T, Bässler C, Löffler F, Müller J, Strätz C, Seibold S. 2017. Small-Scale Positive Response of Terrestrial Gastropods to Dead-Wood Addition is Mediated by Canopy Openness. Forest Ecology and Management 396, 85-90. DOI: 10.1016/j.foreco.2017.03.034.

11. Kottè-mapoko EF, Ngo-massou VM, EssomèKoum LG, Emane JM, Moussian LN, Tchoffo R, Din N. 2017. Molluscs' Composition and Distribution in Mangroves of the Cameroon Central Coast. International Journal of Research Studies in Biosciences 5(5), 4-13. DOI: 10.20431/2349-0365.0505002.

12. Manullang T, Bakti D, Leidonald R. 2018. Structure of Gastropod Communities at Mangrove Ecosystem in Lubuk Kertang Village, West Berandan District, Langkat Regency, North Sumatera Province. IOP Conference Series: Earth and Environmental Sciences 122(1), 12103. DOI: 10.1088/1755-1315/122/1/012103.

13. Merly SL, Elviana S. 2017. Korelai Sebaran Gastropoda dan Bahan Organik Dasar pada Ekosistem Mangrove di Perairan Pantai Payum, Merauke. Agricola 7(1), 56-67.

14. Mulya MB, Arlen HJ. 2018. Production of Litter and Detritus Related to the Density of Mangrove. IOP Conference Series: Earth and Environmental Science, 130(1), 12033. DOI: 10.1088/1755-1315/130/1/012033.

15. Picardal RM, Dolorosa RG. 2014. The Mollus- 
can Fauna (Gastropods and Bivalves) and Notes on Environmental Conditions of Two Adjoining Protected Bays in Puerto Princesa City, Palawan, Philippines. Journal of Entomology and Zoology Studies 2 (5), 72-90.

16. Premcharoen S, Witirawat S, Tharapoom P. 2016. Molluscan Fauna in Bang Taboon Mangrove Estuary, Inner Gulf of Thailand: Implications for Conservation and Sustainable Use of Coastal Resources. MATEC Web of Conferences 60, 2003. DOI: 10.1051/matecconf/20166002003.

17. Pribadi R, Hartati R, Suryono CA. 2009. Distribution and composition of Gastropoda in mangrove forests of Segara Anakan Lagoon, Cilacap. Ilmu Kelautan 14, 102-111.

18. Purnamawati AD, Saputra SW, Wijayanto D. 2015. Nilai Ekonomi Hutan Mangrove di Desa Mojo Kecamatan Ulujami Kabupaten Pemalang. MAQUARES 4 (3), 204-213.

19. Raharja GR, Sanjoto TB, Tjahjono H. 2013. Keterlibatan Masyarakat dalam Pengelolaan Ekosistem Mangrove di Desa Mojo Kecamatan Ulujami Kabupaten Pemalang. Geo Image 2 (2), 56-62.

20. Ramanibai R, Govindan S. 2018. Mollusc Diversity at Pulicat Lagoon (India). Transylc. Rev. Syst. Ecol. Res. 20 (1), 31-42. DOI: 10.1515/trser-2018-0003.

21. Renta PP, Pribadi R, Zainuri M, Angraini M, Utami F. 2016. Struktur Komunitas Mangrove di Desa Mojo Kabupaten Pemalang Jawa Tengah. Jurnal Enggano 1 (2), 1-10.

22. Santhiya N, Sanjeevi SB, Gayathri M, Dhanalakshmi M. 2013. Economic Importance of Marine Molluscs. Research in Environment and Life Sciences 6 (4), 129-132.

23. Seena S, Carvalho F, Cássio F, Pascoal C. 2017. Does the developmental stage and composition of riparian forest stand affect ecosystem functioning in streams? Science of the Total Environment 609, 1500-1511. DOI: 10.1016/j.scitotenv.2017.07.252

24. Silaen IF, Hendrarto B, Supardjo MN. 2013. Distribusi dan Kelimpahan Gastropoda pada Hutan Mangrove Teluk Awur Jepara. Maquares, 2(3), 93-103.

25. Suryanti, Hartoko A, Sari RK. 2017. Relation Analyse of TSS with Abundance of Gastropod Using Landsat Sattelite Imagery in Nongsa Beach Batam. Journal of Biodiversity and Environmental Sciences 10(2): 213-219

26. Tambayong F.A., Rudiyanti S., Suryanti. 2016. Hubungan Kandungan Bahan Organik dengan Distribusi dan Keanekaragaman Gastropoda pada Ekosistem Mangrove di Desa Pasar Banggi Kabupaten Rembang. In: Seminar Nasional Hasil-Hasil Penelitian Perikanan Dan Kelautan Ke-VI, Wirasatriya A., Suryanti, Kurohman F., T WT, Nirwani, K RA, Fitri ADP, WDP, Hartati R., Helmi M. (Eds). Fakultas Perikanan dan Ilmu Kelautan Universitas Diponegoro: Semarang; 601-610.

27. Tavares DS, Maia RC, Rocha-Barreira C, MatthewsCascon H. 2015. Ecological Relations Between Mangrove Leaf Litter and the Spatial Distribution of the Gastropod Melampus coffeus in A Fringe Mangrove Forest. Iheringia. Série Zoologia 105(1), 35-40. DOI: 10.1590/1678-4766201510513540.

28. Zaman MB, Jahan MS. 2013. Food and Feeding Habits of Mangrove Shellfish, Telescopium telescopium (Linnaeus, 1758) in Bangladesh. Bangladesh Journal of Zoology, 41(2), 233-239.

29. Zvonareva S, Kantor Y, Li X, Britayev T. 2015. Long-Term Monitoring of Gastropoda (Mollusca) Fauna in Planted Mangroves in Central Vietnam. Zoological Studies, 54, 39. DOI: 10.1186/ s40555-015-0120-0. 